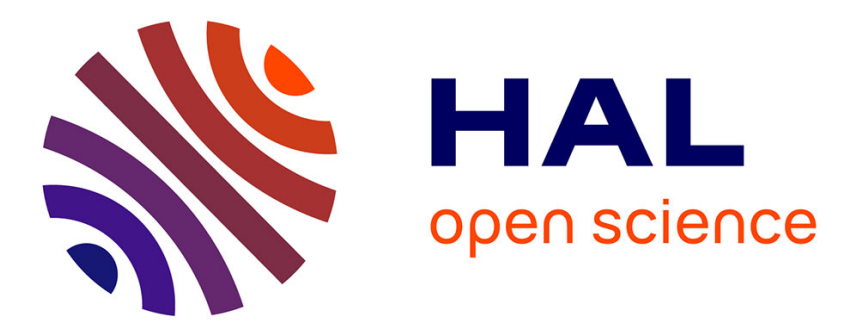

\title{
Mapping wildfire danger at regional scale with an index model integrating coarse spatial resolution remote sensing data
}

\author{
Veronique V. Cheret, Jean-Philippe J.-P. Denux
}

\section{- To cite this version:}

Veronique V. Cheret, Jean-Philippe J.-P. Denux. Mapping wildfire danger at regional scale with an index model integrating coarse spatial resolution remote sensing data. Journal of Geophysical Research, 2007, 112 (G2), 11 p. 10.1029/2005JG000125 . hal-02655696

\section{HAL Id: hal-02655696 \\ https://hal.inrae.fr/hal-02655696}

Submitted on 29 May 2020

HAL is a multi-disciplinary open access archive for the deposit and dissemination of scientific research documents, whether they are published or not. The documents may come from teaching and research institutions in France or abroad, or from public or private research centers.
L'archive ouverte pluridisciplinaire HAL, est destinée au dépôt et à la diffusion de documents scientifiques de niveau recherche, publiés ou non, émanant des établissements d'enseignement et de recherche français ou étrangers, des laboratoires publics ou privés. 


\title{
Mapping wildfire danger at regional scale with an index model integrating coarse spatial resolution remote sensing data
}

\author{
Véronique Chéret $^{1}$ and Jean Philippe Denux ${ }^{1}$ \\ Received 4 November 2005; revised 7 November 2006; accepted 10 November 2006; published 18 April 2007.
}

[1] Wildfires are a prevalent natural hazard in the south of France. Planners need a permanent fire danger assessment valid for several years over a territory as large and heterogeneous as Midi-Pyrénées region. To this end, we developed an expert knowledgebased index model adapted to the specific features of the study area. The fire danger depends on two complementary elements: spatial occurrence and fire intensity. Among the GIS layers identified as input variables for modeling, vegetation fire susceptibility is one of the most influent. However, the main difficulty at this scale is the scarcity or the lack of exhaustiveness of the data. In this respect, remote sensing imagery is capable of providing relevant information. We proposed to calculate an annual relative greenness index (annual RGRE) that reflects vegetation dryness in summer. We processed times series of Normalized Difference Vegetation Index (NDVI) from SPOT-VEGETATION images over the last six available years (1998 to 2003). The first step was to verify that these images characterize vegetation types and highlight intraannual and interannual response variability. It is then possible to identify phenological stages corresponding to the maximum NDVI (and therefore to maximum photosynthetic activity) during the growing season, the minimum NDVI at the end of the growing season and the minimum NDVI during winter period. These phenology metrics ground the annual RGRE calculation.

Values obtained for each observation year show significant correlation $\left(r^{2}=0.70\right)$ with the De Martonne aridity index calculated for the same period. A synthesis of yearly index was integrated in the model as a variable that expresses fire susceptibility.

Citation: Chéret, V., and J. P. Denux (2007), Mapping wildfire danger at regional scale with an index model integrating coarse spatial resolution remote sensing data, J. Geophys. Res., 112, G02006, doi:10.1029/2005JG000125.

\section{Introduction}

[2] Wildfires are a prevalent natural hazard in the South of France. Every year, an average of 23,000 ha of vegetation burns across forests, heath and scrublands areas, with about 5000 fires occurring. In 2003, the extent of the burnt area was 73,000 ha as a result of exceptional climatic conditions. Moreover, fire risks are constantly rising owing to the changes of land and forest uses. For example, forested areas are rising because of agricultural set-aside and sylvopastoralism decline, residential land encroaches on woodland areas increasing wildland-urban interface areas. Consequently, fire risk planning authorities have stepped up their efforts, notably through county- and regional-level fire protection plans. The Midi-Pyrénées region of southwest France is not as vulnerable to wildfires as the Mediterranean departments. Nonetheless it is concerned by the new planning directives, so we need to identify forest areas where fire risk exists. A study was done, with the support of the French National Forestry Office (ONF), to estimate wildland fire danger throughout the Midi-Pyrénées region and to

\footnotetext{
${ }^{1}$ Laboratory of Remote Sensing and Land Management, Graduate School of Purpan, Toulouse, France.

Copyright 2007 by the American Geophysical Union. 0148-0227/07/2005JG000125
}

map static and long-term potential fire danger. For MidiPyrénées, as for other regions in the South of France [Chéret et al., 2003], fire danger mapping is a decision-support tool of genuine utility. It helps to focus fire prevention planning efforts on zones where they are really warranted. Planners need a permanent fire danger assessment valid for several years. A long-term fire danger map sets a territorial order of priority for their actions.

\subsection{Wildland Fire Danger Assessment}

[3] Wildland fire risk is generally considered a combination of two components: fire danger and fire vulnerability [Chuvieco et al., 2003b; Jappiot et al., 2001]. The concept of fire danger is defined as the probability of a fire happening. The fire danger itself depends on two complementary elements: spatial occurrence (the probability of a fire starting or spreading in a given location) and fire intensity (strength of the flame front and potential burnt area). Fire vulnerability refers to the potential human, ecological and economic damages of a fire.

[4] Geographic information systems (GIS) are used increasingly to assess and to map fire risks. Various methods are applied, some of them complex given the number and nature of causal factors integrated into models [Bachmann and Allgöwer, 1998; Castro and Chuvieco, 1998; Farris et al., 1999; Maselli et al., 1996]. Most of these models 


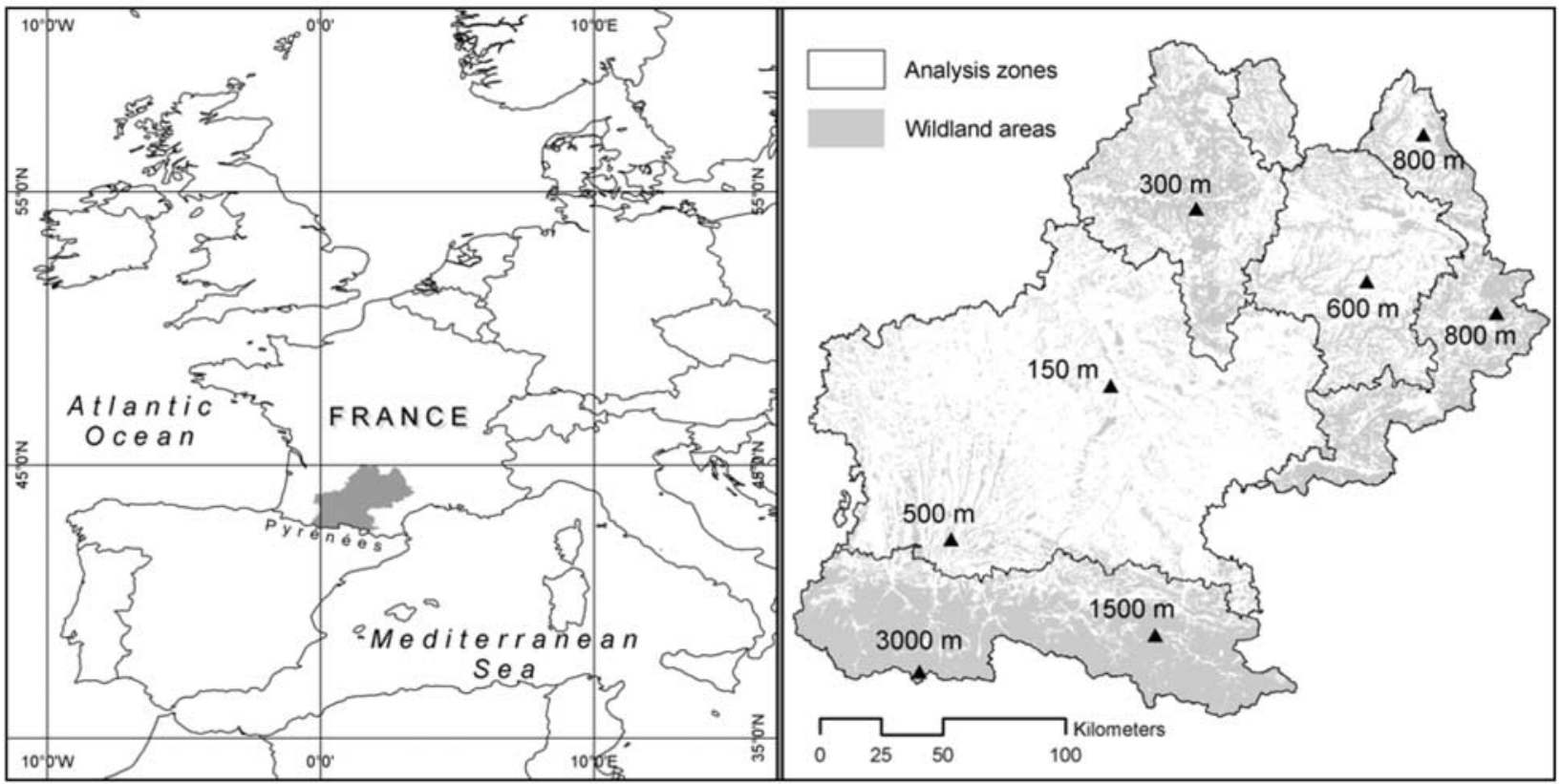

Figure 1. Location map of Midi-Pyrénées region and analysis zones.

integrate the main factors related to fire danger, such as vegetation, topography, fire history and human components. They are based on expertise and experimentation, with results often expressed as an index [Chou, 1992; Chuvieco et al., 2003b].

[5] This paper presents the development and application of a fire danger index model to produce a fire danger map. Fire danger analysis is based on the development of an expert-knowledge-based index model [Chuvieco et al., 2003b; San-Miguel-Ayanz, 2002] adapted to the scale and risk typology of this region. Variables integrated into the model expressed a set of causal factors driving fire occurrence and fire intensity. The analysis had to factor in the region's varied landscapes as well as the special features of human activities impacting fire occurrence.

\subsection{Coarse Spatial Resolution Remote Sensing Data to Assess Vegetation Fire Susceptibility}

[6] Acquiring continuous geographic data to consider the causal factors of fire danger over such a large area, was a determining obstacle to overcome, in particular to characterize fuel condition. Existing indicators and phenological metrics derived from coarse resolution remote-sensing data are not well adapted to assess a long-term (semipermanent) characterization of vegetation fire susceptibility. We aimed to calculate an original vegetation phenology index derived from remote sensing data. A new index based on time series analysis is well adapted to the static model proposed for long-term fire danger assessment.

[7] Vegetation indices derived from the visible and nearinfrared bands are commonly used to characterize vegetation. The Normalized Difference Vegetation Index (NDVI) was defined by J. W. Rouse [Rouse et al., 1974] as NDVI = $(\mathrm{NIR}-\mathrm{R}) /(\mathrm{NIR}+\mathrm{R})$, where $\mathrm{R}$ is the reflectance in the red band and NIR is the reflectance in the near-infrared band. It can be correlated to biophysical vegetation parameters such as active green biomass, photosynthetic activity, leaf area index, or percent vegetation ground cover [Maselli et al., 2004; Pereira et al., 1993; Wang et al., 2005]. Since vegetative activity and physiological conditions are partly dictated by water content, NDVI, often combined with other satellite-derived variables like surface temperature, can be linked to water content to monitor fuel moisture [Alonso et al., 1996; Chuvieco et al., 2004; Dauriac, 2004; Desbois et al., 1997; Deshayes et al., 1998]. NDVI is also used to map fuel types [Keane et al., 2001; Pereira et al., 1993; Riano et al., 2002; van Wagtendonk and Root, 2003]. For this reason, this satellite variable and derived indices are incorporated in many wildfire risk assessment models [Burgan et al., 1998; Gabban et al., 2003; San-Miguel-Ayanz, 2002].

[8] NDVI is widely used to monitor vegetation in a range of ecology applications, especially to detect variations in vegetation distribution and dynamics due to environmental disturbances [Pettorelli et al., 2005]. A number of different methods have been developed to determine seasonal vegetation dynamics. Time series NDVI data can be used to determine the annual cycle of vegetation phenology and calculate the key phenological metrics of the green-up and senescence cycle [Reed et al., 1994; Zhang et al., 2003].

[9] The aim of our study was to identify areas where natural vegetation reaches the highest level of combustibility during the driest period of the year. Time series of satellite imagery afford the ability to observe the seasonal dynamics of vegetation. We sought to calculate a yearly index from NDVI values measured at given times in the annual vegetation cycle to represent its drying intensity in summer. For this purpose, we used time series of SPOTVEGETATION NDVI data.

\section{Study Area}

[10] Covering an area of $45,427 \mathrm{~km}^{2}$, Midi-Pyrénées is France's largest administrative region and one of the most contrasting. Situated in the South of the country, midway 
Table 1. Model Variables and Their Influence on Occurrence and Intensity ${ }^{\mathrm{a}}$

\begin{tabular}{|c|c|c|c|c|c|c|}
\hline \multirow[b]{2}{*}{ Danger Index } & \multirow[b]{2}{*}{ Factors } & \multirow[b]{2}{*}{ Variables } & \multicolumn{2}{|c|}{ Spatial Occurrence } & \multicolumn{2}{|c|}{ Fire Intensity } \\
\hline & & & $\begin{array}{l}\text { Probability of a Fire } \\
\text { Starting in a Given } \\
\text { Location }\end{array}$ & $\begin{array}{c}\text { Probability of a Fire } \\
\text { Spreading in a Given } \\
\text { Location }\end{array}$ & $\begin{array}{c}\text { Potential } \\
\text { Burnt Area }\end{array}$ & $\begin{array}{c}\text { Strength of the } \\
\text { Flame Front }\end{array}$ \\
\hline \multirow{9}{*}{$\begin{array}{l}\text { Potential fire } \\
\text { danger }\end{array}$} & \multirow[t]{3}{*}{ vegetation } & combustible surface area & $\mathrm{x}$ & $\mathrm{xx}$ & $\mathrm{xx}$ & \\
\hline & & vegetation fire susceptibility & $\mathrm{x}$ & $\mathrm{xx}$ & $\mathrm{xx}$ & $\mathrm{x}$ \\
\hline & & continuity of combustible area & & $\mathrm{xx}$ & $\mathrm{x}$ & \\
\hline & \multirow{3}{*}{$\begin{array}{l}\text { topographic } \\
\text { conditions }\end{array}$} & solar exposure & $\mathrm{x}$ & $\mathrm{x}$ & $\mathrm{x}$ & $\mathrm{x}$ \\
\hline & & slope & & $\mathrm{xx}$ & $\mathrm{x}$ & $\mathrm{x}$ \\
\hline & & $\begin{array}{l}\text { exposure to prevailing } \\
\text { wind }\end{array}$ & & $\mathrm{x}$ & $\mathrm{xx}$ & $\mathrm{x}$ \\
\hline & \multirow[t]{3}{*}{$\begin{array}{l}\text { compounding } \\
\text { human } \\
\text { activities }\end{array}$} & $\begin{array}{l}\text { variation in population } \\
\text { and residential } \\
\text { development }\end{array}$ & $\mathrm{xx}$ & $\mathrm{xx}$ & $\mathrm{x}$ & \\
\hline & & $\begin{array}{l}\text { changes in farming } \\
\text { activities (set-aside, } \\
\text { pasture burning), }\end{array}$ & $\mathrm{xx}$ & $\mathrm{x}$ & $\mathrm{x}$ & \\
\hline & & tourist pressure & $\mathrm{xx}$ & $\mathrm{x}$ & & \\
\hline \multirow{3}{*}{$\begin{array}{l}\text { Historical fire } \\
\text { danger }\end{array}$} & \multirow[t]{3}{*}{ history of fires } & number of fires & $\mathrm{xx}$ & & & \\
\hline & & burnt area & & $\mathrm{xx}$ & & \\
\hline & & $\begin{array}{l}\text { cause and period of fire } \\
\text { start }\end{array}$ & $\mathrm{xx}$ & & & \\
\hline
\end{tabular}

${ }^{a}$ Here $\mathrm{x}$ denotes medium influence; $\mathrm{xx}$ denotes high influence.

between the Mediterranean and the Atlantic Ocean (Figure 1), it has a great variety of landscapes and climatic conditions. The relief is characterized by large landform features running southwest to northeast, from the lofty peaks of the Pyrenees forming an east-west chain of contrasting relief (elevation 400 to $3300 \mathrm{~m}$ ) to the foothills of the Massif Central, with its hills, ridges and wide plateaus (elevation 300 to $1400 \mathrm{~m}$ ). A large basin lies in the centre of the region, where the relief is relatively flat (elevation 100 to $500 \mathrm{~m}$ ). The opposing influences of the Atlantic and Mediterranean climates are constantly felt, the former bringing mild winters and precipitation, and the latter hot summers. Precipitation varies spatially from $600 \mathrm{~mm}$ in the centre of the region to more than $1100 \mathrm{~mm}$ in the mountains.

[11] This broad variety of stational conditions has a direct bearing on the type and distribution of natural vegetation. According to the French National Forest Inventory (IFN) forest covers $26 \%$ of the total surface area, and $84 \%$ of this surface area is populated with broadleaf species (high oak forest and coppices, and miscellaneous species).

[12] For wildland fire danger assessment, we have to take into account the great variety of natural landscapes and their vegetation cover. We therefore divided the territory into five large units corresponding to our analysis zones (Figure 1). These units exhibit the specific characteristics of ancient mountain terrain with smoothed peaks, lofty mountain terrain, large alluvial plains, karst limestone plateaus and high schist plateaus.

\section{Methods}

\subsection{Identification of Variables for the Fire Danger Index Model}

[13] Our study focused on a spatial assessment of fire danger, looking at the main causal factors: fuel type and condition, human activities and ignition causes, topography and fire history. Analysis developed an expert knowledge- based index model adapted to the scale and risk typology of the study area. Input variables are considered stable-in-time, since they change slowly. The aim here was therefore to design and apply a "static" model, referred to in the literature as a long-term or structural fire danger index model [San-Miguel-Ayanz, 2002] different from daily danger estimation for operational use.

[14] The choice of variables to be integrated in the model and the procedure for GIS combination and weighting were defined on the basis of expert knowledge of wildland fire danger characteristics in each of the analysis zones. This approach was built on an understanding of the context, causes and nature of fires that occur in the territory studied.

[15] Using an analytical approach, and after performing a diagnosis for each of the analysis zones with all stakeholders, we chose variables and mapped them to take into account the natural and human factors (Table 1). Our choice was constrained by the observation scale and exhaustiveness of the data. Variables were quantified and the value scale expresses the extent of their contribution to fires [Kalabokidisa et al., 2002].

[16] To assess the "potential" fire danger, we looked at factors that have a bearing on spatial occurrence and fire intensity. Incorporating data on past fires to assess the "historical" fire danger provided additional input for the model on fire occurrence.

3.1.1. Input Variables for Potential Fire Danger Index [17] Information on potential fire danger factors, and in particular vegetation fire susceptibility, remains difficult to obtain, because data are seldom available, especially at regional scales. However, this factor is very important, since it is directly related to fire ignition and propagation. As a starting point, we used a French National Forest Inventory (IFN) map to ascertain the nature of forest stands and their acreages. This forest map provides information about the combustible surface area. However, this does not give us direct information on vegetation fire susceptibility, 
which exhibits large spatial variations given the type of vegetation and environmental conditions in the MidiPyrénées region. We therefore used remote-sensing data to fill the gaps in our information. We used satellite imagery to map an index showing drought impact on vegetation and therefore fire susceptibility. Before being integrated in the model, the annual results had to be synthesized to express a semipermanent index. The method will be detailed in the next section.

[18] The centre of the Midi-Pyrénées region is characterized by sparse and fragmented woodland areas. The discontinuity of vegetation cover was introduced as a factor that reduces danger levels by slowing fire spread. GIS spatial analysis capability provides landscape analysis tools, among them we use the Mesh index [Jaeger, 2000] to reckon the fragmentation of wildland areas.

[19] The topographic layers taken into account are variables usually known for their direct effects on fire propagation or indirect effects on vegetation moisture content. The slope and solar exposure layers were derived from a digital elevation model generated by the French Mapping Agency (IGN). Then it was processed with wind data from the Meteo-France observation network, to build the wind exposure layer.

[20] Human activities also have a major bearing on fire danger in two ways. First, official statistics realized by the "Service central des enquêtes et études statistiques" (SCEES) of the Ministry of Agriculture and PROMETHEE fire database (http://www.promethee.com) show that the main causes of fire are human, either by carelessness or arson. Second, changes in the way rural lands and farmland are managed and maintained can increase fire danger, for example by extending the combustible surface area. As a result of agricultural set-aside and depopulation, rural lands are being maintained less and less. Fallow land growing to wooded areas are gaining ground over fields and pastures, leading to the gradual spread of a forest continuum with no natural fire breaks. The enhanced enthusiasm for nature is bringing increased numbers of tourists and holiday dwelling in wildland and forested areas, thereby raising the probability of fire ignition. This is particularly true in the popular tourist area of northwest Midi-Pyrénées region. Another causal factor is the burning of grasslands to maintain summer pasture. This practice is common where pastoral farming has survived, especially in the Pyrénées, and is the main cause of fire starts. Burning is often poorly controlled because the right means of action is lacking, and fire spreads across heathland in sunny expositions and sometimes to surrounding wooded areas. To take into account these factors, the variables choices were based mainly on the analysis of existing statistical data, they were then integrated to index calculations.

3.1.2. Input Variables for Historical Fire Danger Index [21] Fire history data are based on real observations strengthening assessment of fire occurrence. Variables like number of fires, burnt areas and causes, indirectly express the human influence, since most fires are of anthropogenic origin. While certain inventory data sometimes lack precision, particularly for estimated burnt area, fire history data tell us what most often caused fires to start and what periods of the year fire occurrence is most likely, while indicating the overall extent of areas affected by fire. This kind of information is vital when defining a fire typology for the different analysis zones. Frequency of fire occurrence identifies sites where specific causes are concentrated, such as pasture burning in mountain zones. If only potential causal factors related to the natural environment are taken into account, the fire danger may be underestimated.

[22] A historical fire database has been available since 1992 (SCEES). The statistics office records fires not by geographic location but by administrative unit (municipality). Consequently, it is impossible to interpolate using tried-and-tested methods [de la Riva et al., 2004] and data can only be combined with other information layers at municipality level. Most fires are quickly brought under control, so burnt areas are too small $(90 \%$ cover less than $5 \mathrm{ha})$ to be mapped from available remote-sensing data.

\subsection{Vegetation Fire Susceptibility Mapping With SPOT-VEGETATION Imagery}

\subsubsection{Satellite Data}

[23] SPOT-VEGETATION imagery is acquired daily at a spatial resolution of $1 \mathrm{~km}$. The data set consists in four optical spectral bands, B0, B2, B3 and SWIR, corresponding to the blue $(0.43-0.47 \mathrm{~mm})$, red $(0.61-0.68 \mathrm{~mm})$, near-infrared $(0.78-0.89 \mathrm{~mm})$ and short-wave infrared $(1.58-1.75 \mathrm{~mm})$ domains [Arnaud and Leroy, 1991]. To reduce data errors due to atmospheric noise, clouds, viewing conditions and sensor deficiencies, synthesis products are processed at the Image Processing Centre at Vito in Belgium [Passot, 2001]. The 10-day synthesis products acquired since April 1998 are available 3 months after insertion in the VEGETATION archive from http://free. vgt.vito.be/. The data set used for this study covers 1998 to 2003 .

\subsubsection{Analysis of NDVI Time Series for Phenological} Metrics

[24] We began our study by verifying the potential of NDVI imagery for discriminating vegetation types and observing variability in intraseasonal and interannual response. Using the forest boundaries in the IFN map and the 6-year time series, we extracted a mean NDVI value for the dominant types of vegetation in each analysis zone. Since each vegetation type has its own seasonal dynamics, we can assume that it exhibits a specific NDVI profile. We calculated the integrated NDVI over the summer season, which can be interpreted as the photosynthetic activity in the growing season [Reed et al., 1994]. The integrated NDVI was then processed for each vegetation type and for each year from 1998 to 2003. An analysis of variance was used to verify that they are significantly different.

\subsubsection{Estimating Vegetation Status From NDVI}

[25] Many indices derived from NDVI are used to synthesize vegetation behavior. The Vegetation Condition Index (VCI) was proposed by Kogan in 1990 to evaluate the global weather impact on vegetation, and more particularly the impact of drought on farming [Kogan et al., 2003]. Also called the Relative Greenness index (RGRE), this indice is a relative measurement of the NDVI value at observation date with respect to extreme conditions estimated by calculating a maximum and minimum NDVI over a reference period. It is calculated as follows: $\mathrm{RGRE}=\left(\mathrm{NDVI}_{0}-\mathrm{NDVI}_{\min }\right) /$ $\left(\mathrm{NDVI}_{\max }-\mathrm{NDVI}_{\min }\right)$, where RGRE is the relative percent green at observation date, $\mathrm{NDVI}_{0}$ is the NDVI value at 


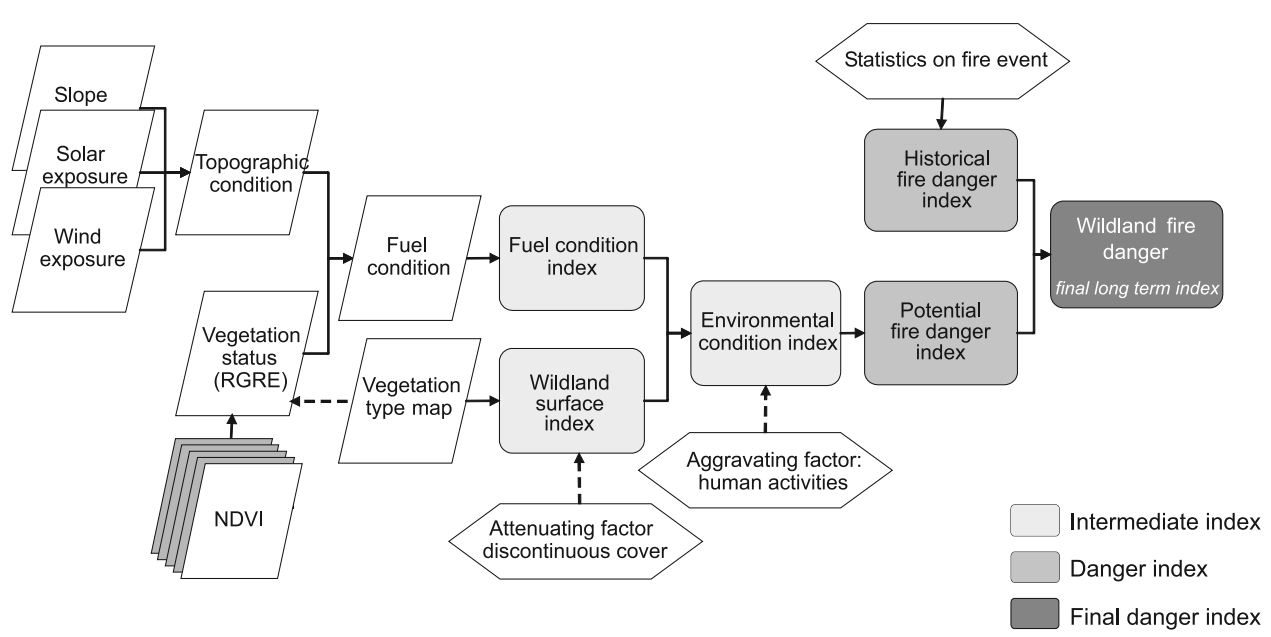

Figure 2. Structure of wildland fire danger model.

observation date for a pixel, $\mathrm{NDVI}_{\max }$ and $\mathrm{NDVI}_{\min }$ the maximum and the minimum NDVI value for that pixel during the whole reference period.

[26] This index subsequently proved useful for evaluating wildfire danger [Martin et al., 1994]. Although establishing a correlation between RGRE and direct measurements of fuel moisture content in natural vegetation is still proving difficult [Chuvieco et al., 2003a], efforts are underway to include this parameter when calculating a daily fire risk index for operational use, such as the Fire Potential Index (FPI) or Dynamic Relative Greenness Index (DRGI) [Burgan et al., 1998; Gabban et al., 2003; Sebastián López et al., 2002]. Initially designed to monitor vegetation in real time, in relation to the range of historical NDVI observations, the RGRE can be adapted to assess drying intensity during a season. In our study, we were looking for a semipermanent indicator of vegetation behavior, so we chose to calculate an original index: the annual RGRE, evaluating the fuel potential of vegetation as it dries during the summer months. This vegetation status index is based on the seasonal characteristics extracted from NDVI time series. Annual RGRE was mapped for each observation year and compared with climate data.

\subsubsection{Comparison of the Annual RGRE With a Climatic Index}

[27] The susceptibility of vegetation to fire is closely related to moisture content; fire danger is higher in natural vegetation affected by water stress. However, conditions conducive to fire susceptibility are not constant, as they are driven above all by the intensity of summer drought.

[28] We consider that the annual RGRE reflects fuel dryness and can be used as a vegetation status input variable. As vegetation dryness in summer is directly related to climatic conditions, particularly precipitation levels, we wanted to verify that the measured index, which varies from year to year, is consistent with the drought intensity observed each year. We therefore sought to compare annual RGRE values with a climatic index that expresses the severity of drought conditions during the growing season.

[29] Research has already shown a close relationship between a meteorological danger index measured in real time and indices derived from NDVI [Aguado et al., 2003; Martin et al., 1994]. For our study, we needed an annual climatic index. We calculated the De Martonne aridity index [de Martonne, 1926; Moisselin et al., 2002] over the growing season from May to September, which is the period used to calculate the annual RGRE. This index is a simple ratio of precipitation by temperature: $\mathrm{IMgs} \mathrm{P} / \mathrm{T}+10$, where $\mathrm{IMgs}$ is the aridity index of the growing season, $\mathrm{P}(\mathrm{mm})$ the total precipitation from May to September, and T (deg C) the mean temperature over the same period. The climatic index was calculated for 13 weather stations of the MétéoFrance network, selected to characterize variations in climatic conditions across Midi-Pyrénées region and located near wildland or forest stands (Figure 5 in section 4.2).

[30] We also extracted average annual RGRE values within a radius of $6 \mathrm{~km}$ around the weather stations. Only one or two types of vegetation predominate at each location. We also consider that the 13 observation points selected are sufficiently representative of the variety of landscapes and environments. We can thus compare RGRE values extracted around these locations, with the aridity index calculated from the weather station data.

\subsection{Modeling Wildland Fire Danger With a Long-Term Index}

[31] The method used to combine all of the quantitative input variables must weight their relative influence on fires. Given the geographic heterogeneity of Midi-Pyrénées region, in terms of its environment, human activities and urban density, intermediate indices were calculated specifically for each analysis zone. The principle used was to apply different "danger weights" at each overlaying step [Kalabokidisa et al., 2002] and according to the influence of the variable on fire danger, as presented in Table 1. Results were adjusted for the territory as a whole when calculating the potential fire danger index.

[32] The structure of the fire danger model is presented in the Figure 2. The vegetation status map resulting from the remote sensing images processing is combined with topographic conditions to define a fuel condition index. This intermediate index overlaid with the wildland surface index map then integrating human activities as an aggravating factor lead to a potential fire danger index map. First processed at pixel level this layer is summarized by municipality to be 


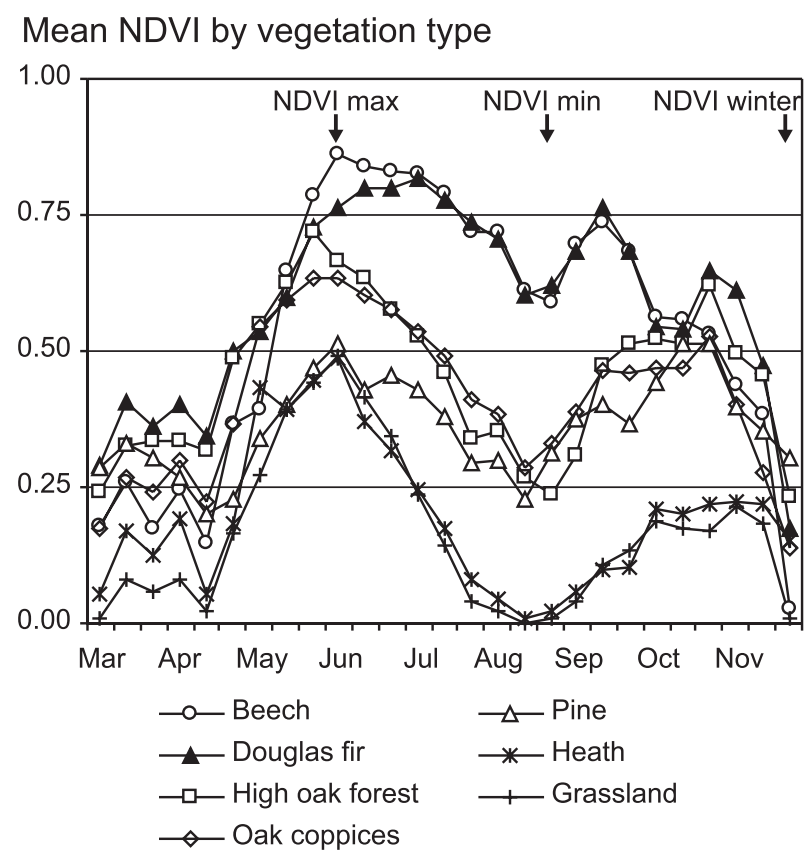

Figure 3. Seasonal variation of NDVI (2000).

combined with the historical fire danger index to give the final wildland fire danger index.

\section{Results}

[33] We begin by presenting the elements used to map vegetation fire susceptibility. This layer was then integrated into the model. The model's components and structure are successively described. The end result is the fire danger map covering the entire study area.

\subsection{Seasonal NDVI Profiles}

[34] Annual NDVI profiles allow us to understand the foremost seasonal characteristics and identify the main phenological metrics, such as the start and duration of the active growing season [Reed et al., 1994]. Temporal NDVI variations indirectly reflect an increase or decrease in active biomass. The amplitude of variations depends on plant species and may vary from one year to another, particularly during senescence in dry climatic conditions.

[35] Seasonal NDVI profiles were established for the 6 years of observation (1998 to 2003). During this period the climatic conditions were varying, with a wet summer (2002) and a extremely dry summer (2003) and more moderate conditions the other years $(1998,2000$ and 2001). The results are presented using the example of 2000 (Figure 3) as a baseline, considered as a typical year with respect to the fire history and yearly climatic conditions. The curves show NDVI variation from March to November 2000 for seven vegetation types in the Northeast of Midi-Pyrénées region, highlighting the transition dates that define the key phases of vegetation phenology during the active growing season. We see that NDVI peaks in late spring/early summer, when maximum greenness is reached. It then falls regularly to a minimum in September, at the end of the greenness period. The increase in NDVI in early autumn can be explained by renewed rainfall. NDVI measurements during this period can also be affected by regained vegetation vigor, particularly in herbaceous vegetation. This seasonal dynamic is apparent in all our analysis zones.

[36] In the same analysis zone and for the same vegetation types, total greenness was calculated by integrating NDVI from May to September for 5 years (1998 to 2002). 2003 was excluded, as the summer drought and heat wave in Europe were exceptional that year in terms of their extent, duration and intensity [Black et al., 2004].

[37] The purpose of comparing integrated NDVI values is to ensure that vegetation types are correctly discriminated. An analysis of variance confirms that the vegetation types are significantly different. The Student test with $\alpha=0.05$ shows a $\mathrm{F}$ value of 79 for a limit value of 2.45 . We therefore identified four significantly different groups (Figure 4): heath and grassland; pine (black and Scots pine); high oak forest and coppices (pubescent and pedunculate oak); beech and Douglas fir. Comparing mean values shows that the integrated NDVI does not distinguish beech and Douglas fir, the two mountain species. This would no doubt have been possible by including the winter period in total greenness calculations. Similar results were obtained for the other analysis zones.

[38] NDVI profiles and phenological metrics clearly illustrate variability of vegetation behavior over time in the study area, and correctly discriminate vegetation types. These initial results confirm that it is possible to use these variables to follow different types of vegetation. We observed that the dryer the summer period is, the more sharply the NDVI value decline at the end of the growing season. Our objective was to exploit this intraseasonal dynamic to calculate a vegetation drying intensity index. We propose to calculate and map an annual relative greenness index (annual RGRE) based on the decrease of NDVI during the summer period.

\subsection{Vegetation Status Mapping With Annual RGRE}

[39] To calculate an annual RGRE, reference periods were derived from seasonal NDVI profiles and observation of phenological metrics corresponding to the maximum NDVI during the growing season and the minimum NDVI at the end of the growing season (Figure 3). We consider

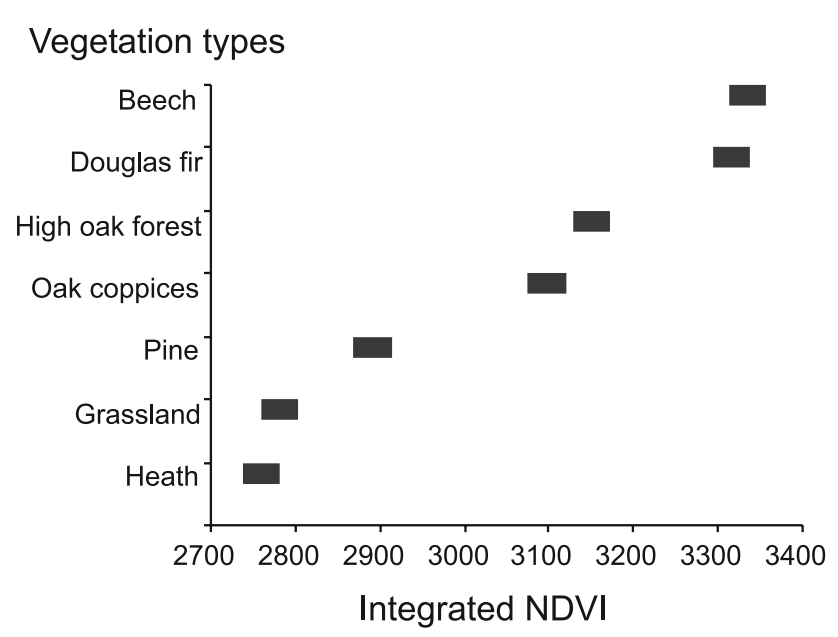

Figure 4. Mean of integrated NDVI with $95 \%$ confidence interval (1998-2002). 


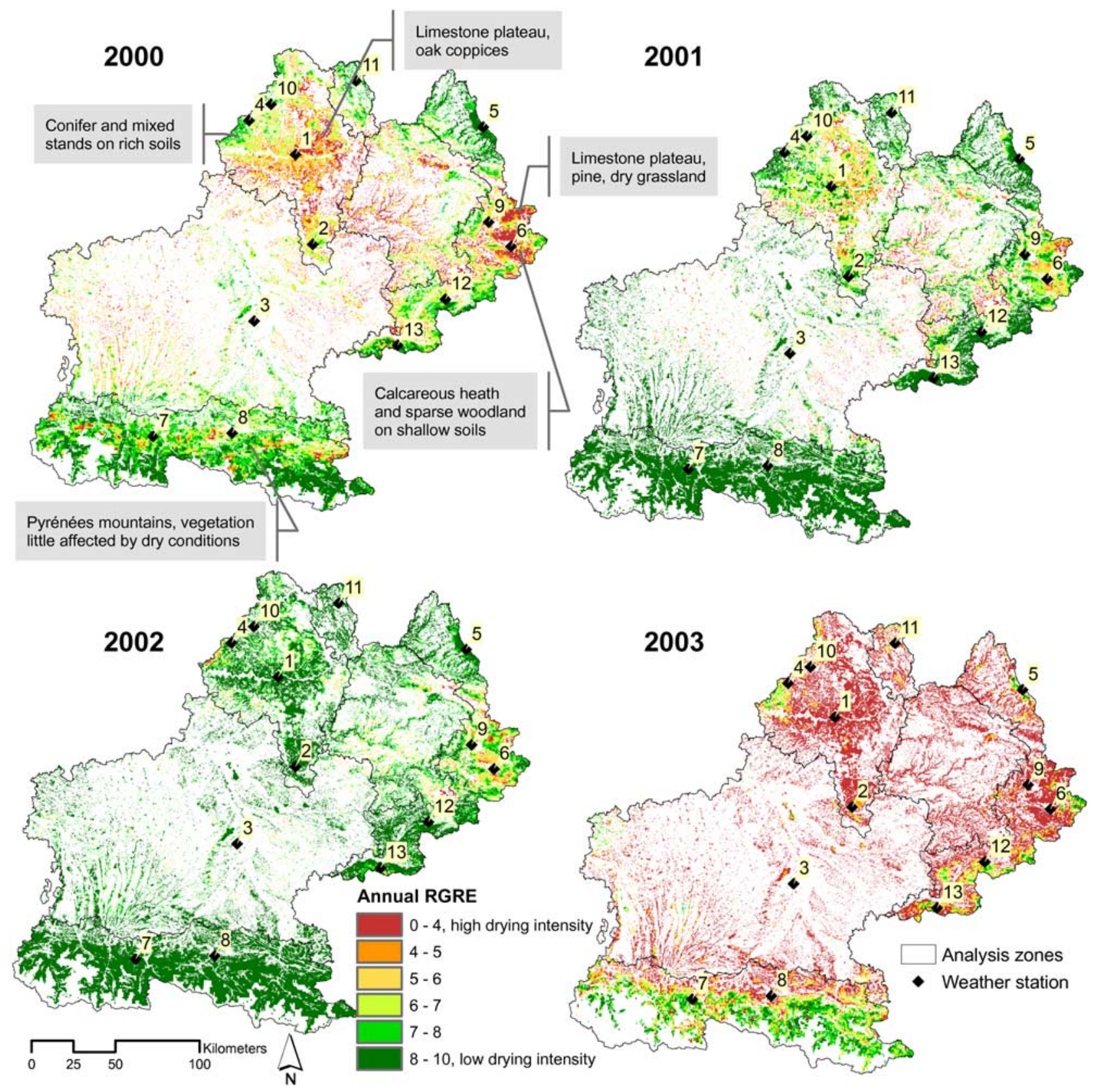

Figure 5. Annual RGRE maps for Midi-Pyrénées region (2000-2003).

that the drop in NDVI recorded after the late spring-early summer peak indicates reduced vegetation vigor related to the drop in vegetation moisture content. The more NDVI falls in summer, the more vegetation water stress and fire susceptibility increase.

[40] We use an annual RGRE index adjusted to the vegetative growing season. The NDVI values taken to cover this period are those obtained from May to September. The annual index is normalized by the winter minimum to take into account vegetation behavior outside the summer period.

[41] For a given pixel, the annual RGRE is obtained from the maximum NDVI observed at the start of the season (May-June), the minimum NDVI attained during the driest period (August-September), and the minimum measured in winter (December-February):

$$
\begin{aligned}
\text { Annual RGRE }= & \left(\mathrm{NDVI}_{\min }-\mathrm{NDVI}_{\mathrm{winter}}\right) \\
& /\left(\mathrm{NDVI}_{\max }-\mathrm{NDVI}_{\text {winter }}\right)
\end{aligned}
$$

$\mathrm{NDVI}_{\max }-\mathrm{NDVI}_{\text {winter }}$ indicates, for a pixel, the amount of living biomass produced during the growing season, while $\mathrm{NDVI}_{\text {min }}-\mathrm{NDVI}_{\text {winter }}$ gives the amount of biomass that is still green at the driest time of the period studied. The ratio between the two (the annual RGRE) corresponds to the proportion of biomass produced during the year that is still green at the end of the dry season. The lower the annual RGRE, the more dead biomass there is and the higher its 
Table 2. Types of Vegetation and Their Locations for Annual RGRE Extraction

\begin{tabular}{ll}
\hline Type of Vegetation & \multicolumn{1}{c}{ Location } \\
\hline High broadleaf forest & north and south \\
Coppice & northeast and northwest \\
Conifer (pine) & northeast \\
Heath & northeast \\
\hline
\end{tabular}

fire susceptibility. Factoring in $\mathrm{NDVI}_{\text {winter }}$ allows us to better discriminate broadleaf trees from conifers, since conifers maintain a higher NDVI in winter when broadleaf species shed their leaves.

[42] Annual RGRE layers were generated from time series of decadal NDVI data, extracted for wildland areas. For high terrain with snow cover throughout winter, the minimum NDVI is hard to measure; the annual RGRE was therefore not calculated for the highest areas in the Pyrenees. The maps obtained for the 4 most recent years are shown in Figure 5. Comparing years, the index exhibits substantial spatial and temporal variability. The lowest values, in red on the maps, indicate locales where vegetation drying intensity was highest. Areas most sensitive to drought are mainly in the north and northeast of Midi-Pyrénées region, where soils are shallow and calcareous, and rainfall is low. These results are consistent with the known locale characteristics, i.e., climate, elevation and soils. Some of these locales are shown in the 2000 map (Figure 5). 2003 is an illustration of extreme summer drought conditions. During summer 2003, water availability was extremely low [Trigo et al., 2005] and the annual RGRE reflects drought-impacted vegetation across the region, with the exception of high terrain and a few wetter areas.

[43] We extracted mean annual RGRE values for the dominant types of vegetation: predominantly oak coppices and high stands, conifers (except firs) and limestone plateau heath. In the study area fir grows above $1000 \mathrm{~m}$ in areas

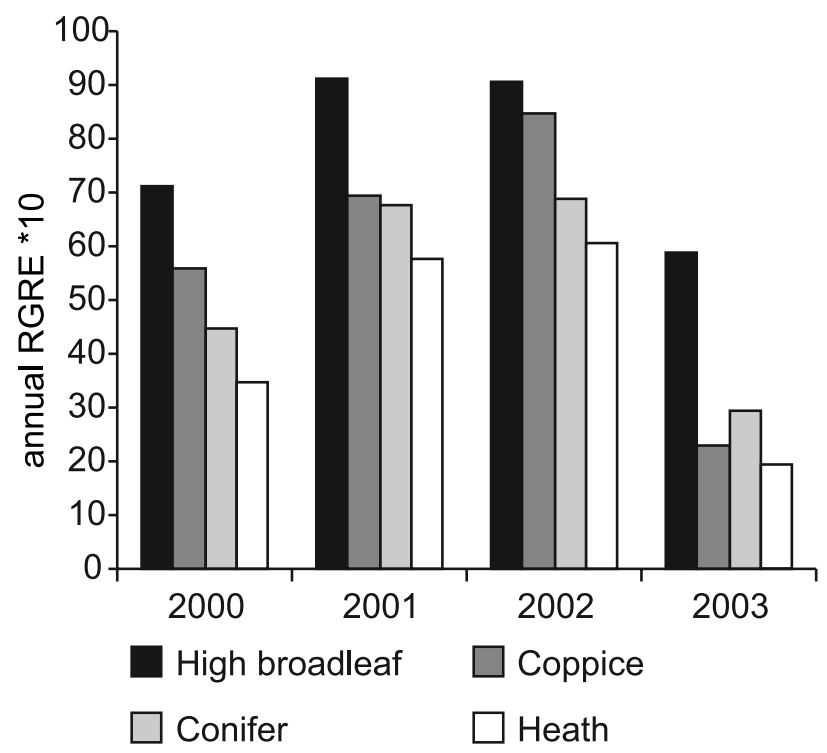

Figure 6. Mean annual RGRE values by type of vegetation. where fire risks are low owing to climatic conditions. Firs stands rarely affected by fire were not taken into account. The places of extraction are presented in Table 2 .

[44] As Figure 6 and Table 3 show, the sequence is virtually the same from one year to the next: maximum values are found for high broadleaf and minimum values for calcareous heath. For these types of vegetation the results are consistent with the levels of fire susceptibility defined by expert knowledge. However, large interannual variations can be measured in particular for coppices and heath (more than $200 \%$ between 2002 , a year when no drought effects were felt, and 2003 when there was a high water deficit). High broadleaf stands exhibited the lowest index variation; for 2001 and 2002, vegetation behavior was identical, whereas a difference, even small, is observed for the other types of vegetation.

\subsection{Correlation of the Annual RGRE With De Martonne Climatic Index}

[45] Interannual variability of vegetation status is related to the severity of drought conditions. We can verify that the lowest annual RGRE values (drought-impacted vegetation) extracted around the weather stations (Figure 5) match the lowest values of the De Martonne aridity index, indicating high drought intensity. Seven stations are shown as an example (Figure 7); the elevation and surrounding types of vegetation are indicated for each. The shape of the curves of annual RGRE from 2000 to 2003 confirms what we have noted about the indices of different types of vegetation and the range of interannual variations: values are high at mountain stations where broadleaf species predominate, with low interannual variations (stations 5 and 7); values are low (maximum $=5.8$ ) for calcareous heath on shallow soil (station 6); there are large interannual variations where coppices predominate (station 1); moderate variations for conifers (station 4); and intermediate variations for combined vegetation types (stations 2 and 3). In every case, the low vegetation index values in 2003 are related to the exceptional dryness that year. In 2002, no water deficit was noticeable (high IMgs) and vegetation index values were maximum at all stations.

[46] Broadly speaking, the curves of both indices exhibit the same trend (Figure 7). However, year 2000 is noteworthy for stations 2 and 6 . The monthly distribution of precipitation at these stations shows that the high IMgs value is due to a peak recorded in September, that is, at the end of the vegetative growing season. This late water supply did not affect vegetation behavior and, therefore, the annual RGRE. This is confirmed by calculating the De Martonne index only for July and August (IMss). The IMss curve closely matches that of the annual RGRE. We can also see that for high IMgs values (station 5), according to the observed data when IMgs is higher than 16, moisture

Table 3. Interannual Variation of Annual RGRE Values

\begin{tabular}{lccc}
\hline & \multicolumn{3}{c}{ Rate of Interannual Variation, \% } \\
\cline { 2 - 4 } & $2000-2001$ & $2001-2002$ & $2002-2003$ \\
\hline High broadleaf forest & 21 & 0 & 54 \\
Coppice & 20 & 18 & 271 \\
Conifer (pine) & 34 & 2 & 134 \\
Heath & 40 & 5 & 213 \\
\hline
\end{tabular}



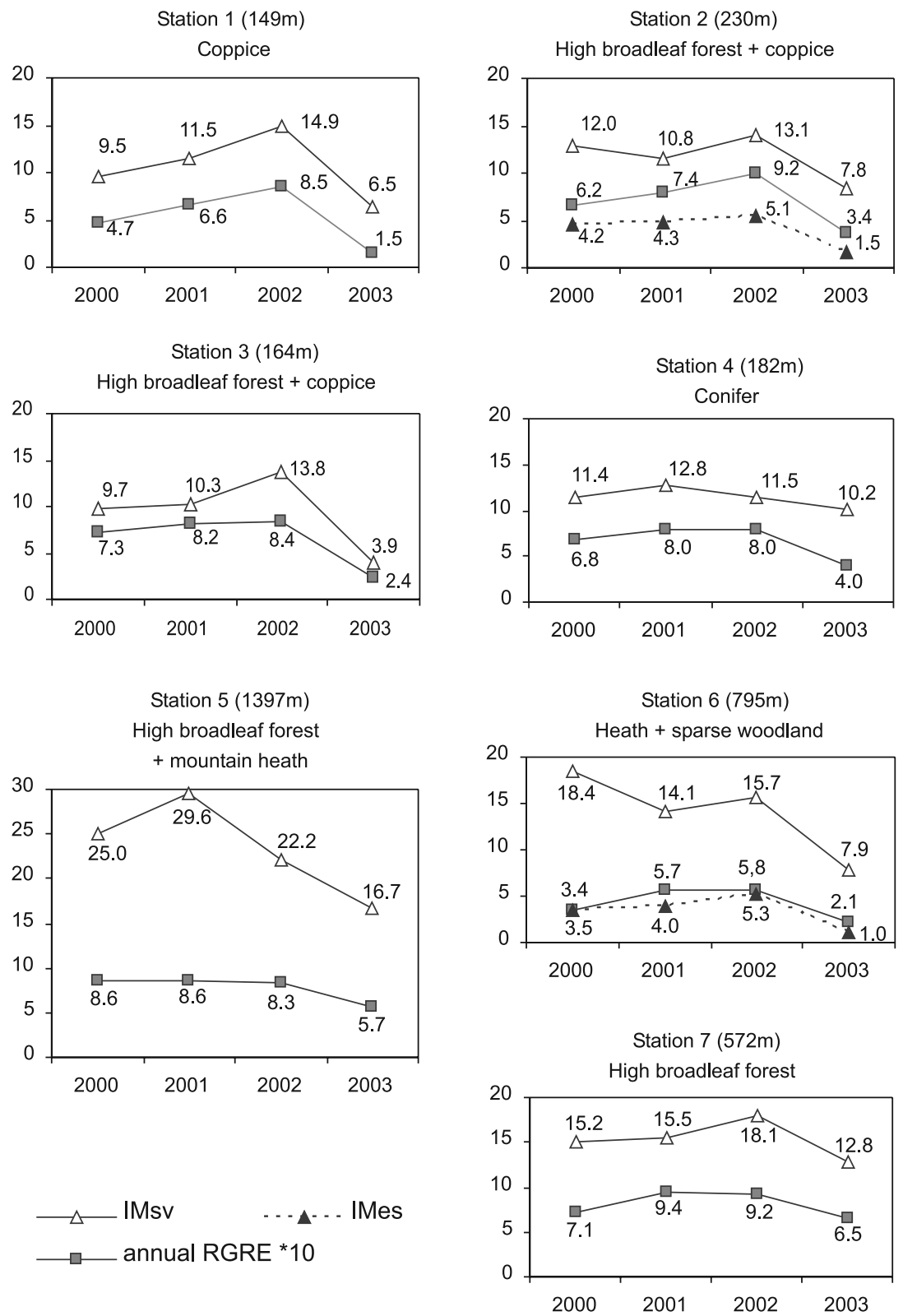

Figure 7. Interannual comparison of climatic indices values and annual RGRE extracted around weather stations (IMgs: De Martonne aridity index of the growing season from May to September; IMss: De Martonne aridity index of the summer season from July and August).

conditions have little influence on the vegetation index. We observe a similar situation at stations at high altitude that only rarely experience a water deficit. As a general rule, annual RGRE variations at the 13 stations are high for IMgs values below 16 .

[47] We calculated a linear regression between the two indices. The IMgs values are used as the dependent variable of the regression, and the annual RGRE as the independent variable. Taking all index values, the linear regression coefficient is statistically significant at $99 \%$ confidence level, with $r^{2}=0.41$ for $n=51$. Moreover selecting IMgs values less than 16 , we obtain a linear regression coefficient of $\mathrm{r}^{2}=0.70$ for $\mathrm{n}=30$ (Figure 8 ), which demonstrates a highly significant correlation at $99 \%$ confidence level. These results show that measuring vegetation status with the annual RGRE reflects variations in weather conditions due to precipitation.

\subsection{Mapping the Fire Danger Index}

[48] An average annual RGRE index was mapped from observed data except year 2003. According to the previous results, this average index can be chosen as a variable that expresses fire susceptibility related to vegetation dryness.

[49] Data on environmental conditions and human parameters were combined according to the model (Figure 2). In the final map (Figure 9), fire danger is classified as none, low, moderate or high. This map spatially quantifies the fire danger at a regional scale and is quite relevant for defining priority areas for fire prevention and mitigation plans mandated by forestry regulations. Forest stands where fire 


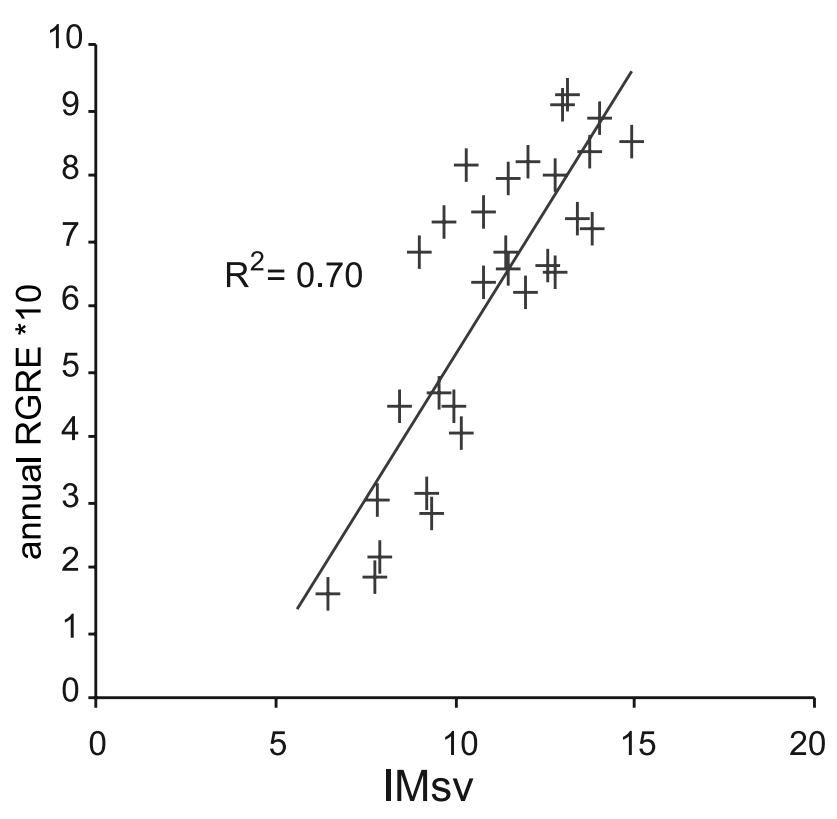

Figure 8. Linear regression between levels of annual RGRE and values of the aridity index of the growing season (IMgs) less than 16 (significant at 99\% confidence level).

danger is classified as "none" or "low" need not be included in such plans. In areas where fire danger is higher, priority actions can be undertaken to reduce risk factors and choose appropriate fire fighting management and resources.

\section{Discussion and Conclusion}

[50] In response to changing public perceptions, fire risk planning and mitigation are being strengthened, now including regions where wildfire risks are low and scattered. For these territories, assessment of fire danger requires the index model to be adapted to the specific features of the natural and human environment. The choice of weighting variables and a scheme for integrating them is based on expert knowledge. This is the strength of the process and at the same times its limitation. Likewise, results validation relies mainly on expertise. Unlike in other studies [Burgan et al., 1998; Castro and Chuvieco, 1998; Gabban et al., 2003], we cannot use fire history statistics to validate results because these data are already integrated in the model.

[51] Remote-sensing data, used to calculate the annual RGRE qualifying summer vegetation dryness, yielded detailed and homogeneous information on vegetation fire susceptibility that no other database could have provided over such a large area. The annual RGRE, complemented by existing forest maps, was directly incorporated in the wildfire danger assessment model. We were also able to show that annual RGRE variations are consistent with the De Martonne aridity index measured over the same period. However, the analysis of monthly distribution of precipitation may be required to evaluate this relationship. Water supply during winter and early spring is not taken into account, therefore moisture conditions before the start of growing season may influence vegetation behavior in summer. Likewise, heavy precipitation toward the end of the summer will have little effect on vegetation phenology, but impact the aridity index. These results illustrate the difficulties to establish a relationship between meteorological indices and vegetation indices measured by remote sensing [Maselli, 2004].

[52] We were able to show for the study area that vegetation is strongly influenced by the variations of moisture conditions and that temporal NDVI profiles are contrasting from one species and one year to another. Vegetation types studied exhibit relatively typical phenological characteristics, with a cycle of growth and decline from May to September. In Mediterranean environments, we can suppose that vegetation behavior is more complex because species are more adapted to drought, with less NDVI variability in summer and a possible growth phase in autumn. The development of fire danger assessment based on the annual RGRE is an interesting challenge for Mediterranean regions, where the fire risk is high. However, it will be necessary to adjust the annual RGRE calculation to drought-adapted vegetation using specific phenology metrics. Like for the Midi-Pyrénées region, we could establish a benchmark of annual vegetation dryness maps. A posteriori analysis of these data, related to statistics on fire events and climatic data, would be useful to fire managers to review planning and firefighting resources implemented in previous years. A purpose could also be to assess the capability of vegetation phenology metrics to provide early information on potential fire danger at the beginning of the dry period.

[53] SPOT-VEGETATION imagery is available for all years since 1998, so we can establish a genuine benchmark of annual RGRE maps by vegetation type. Besides being used to assess wildland fire danger, these data can also bring direct benefits for forest managers. For example, in MidiPyrénées region they are currently seeking to locate and monitor forest stands that have been repeatedly affected by high water stress in recent dry years. Pre-2003 data can provide an appropriate NDVI baseline reference. The analysis

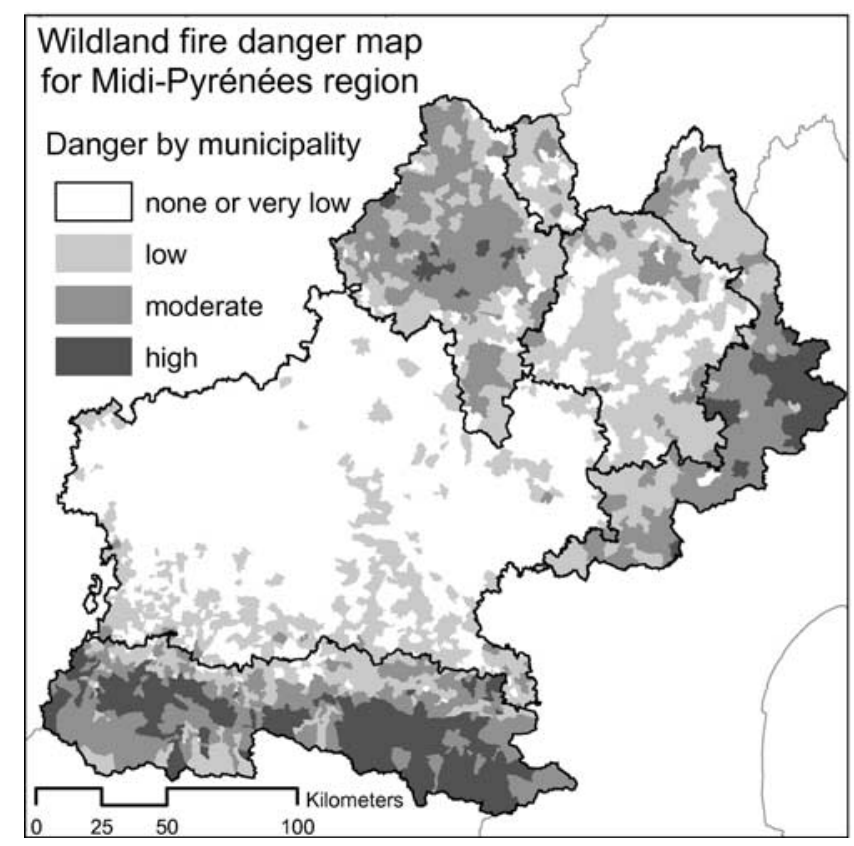

Figure 9. Final map. 
of changes in post-2003 vegetation phenology metrics could then allow us to map areas where forest decay following the abnormally dry summer of 2003 and the drought of 2005 is suspected.

\section{References}

Aguado, I., E. Chuvieco, P. Martin, and J. Salas (2003), Assessment of forest fire danger conditions in southern Spain from NOAA images and meteorological indices, Int. J. Remote Sens., 24(8), 1653-1668.

Alonso, M., A. Camarasa, E. Chuvieco, D. Cocero, I. Kyun, P. Martin, and J. Salas (1996), Estimating temporal dynamics of fuel moisture content of Mediterranean species from NOAA-AVHRR data, EARSeL Adv. Remote Sens., 4(XI), 9-24.

Arnaud, M., and M. Leroy (1991), SPOT 4: A new generation of SPOT satellites, IPRS J. Photogramm. Remote Sens., 46, 205-215.

Bachmann, A., and B. Allgöwer (1998), Framework for the assessment of wildfire risk, paper presented at 3rd International Conference on Forest Fire Research/14th Conference on Fire and Forest Meteorology, Univ. of Coimbra, Luso, Portugal.

Black, E., M. Blackburn, G. Harrison, and J. Methven (2004), Factors contributing to the summer 2003 European heatwave, Weather, 59, $217-223$.

Burgan, R. E., R. W. Klaver, and J. M. Klaver (1998), Fuel models and fire potential from satellite and surface observations, Int. J. Wildland Fire, 8(3), 159-170.

Castro, R., and E. Chuvieco (1998), Modeling forest fire danger from geographic information, Geocarto Int., 13(1), 15-23.

Chéret, V., J. P. Denux, and M. Gay (2003), Cartographie des aléas "incendies de forêts" pour la prescription de PPRI sur les communes de l'Aude, study report-DDA de l'Aude, 42 pp., Lab. de Télédétection et de Gestion des Territoires, ESAP, Toulouse, France.

Chou, Y. H. (1992), Management of wildfires with a geographical information system, Int. J. Geogr. Inf. Syst., 6(2), 123-140.

Chuvieco, E., I. Aguado, D. Cocero, and D. Riano (2003a), Design of an empirical index to estimate fuel moisture content from NOAA-AVHRR images in forest fire danger studies, Int. J. Remote Sens., 24(8), 16211637.

Chuvieco, E., B. Allgöwer, and J. Salas (2003b), Integration of physical and human factors in fire danger assessment, in Wildland Fire Danger Estimation and Mapping: The Role of Remote Sensing Data, pp. 197-218, World Sci., Hackensack, N. J.

Chuvieco, E., D. Cocero, D. Riano, P. Martin, J. Martinez-Vega, J. de la Riva, and F. Perez (2004), Combining NDVI and surface temperature for the estimation of live fuel moisture content in forest fire danger rating, Remote Sens. Environ., 92(3), 322-331.

Dauriac, F. (2004), Suivi multi-échelle par télédétection et spectroscopie de l'état hydrique de la végétation méditerranéenne pour la prévention du risque de feu de forêt, Ph.D. thesis, 297 pp., Ecole Natl. du Génie Rural des Eaux et des Forêts, Montpellier, France.

de la Riva, J., F. Perez-Cabello, N. Lana-Renault, and N. Koutsias (2004), Mapping wildfire occurrence at regional scale, Remote Sens. Environ., 92(3), 363-369.

de Martonne, E. (1926), Aréisme et indice d'aridité, C. R. Acad. Sci., 182(23), 1395-1396.

Desbois, N., J. M. Peirera, A. Beaudoin, E. Chuvieco, and A. Vidal (1997), Short term fire risk mapping using remote sensing, in A Review of Remote Sensing Methods for the Study of Large Wildland Fires, edited by E. Chuvieco, pp. 29-60, Univ. de Alcalà, Alcalà de Henares, Spain.

Deshayes, M., E. Chuvieco, D. Cocero, M. Karteris, N. Koutsias, and N. Stach (1998), Evaluation of different NOAA-AVHRR derived indices for fuel moisture content estimation: Interest for short-term fire risk assessment, paper presented at 3rd International Conference on Forest Fire Research/14th Conference on Fire and Forest Meteorology, Univ. of Coimbra, Luso, Portugal.

Farris, C. A., C. Pezeshki, and L. F. Neuenschwander (1999), A comparison of fire probability maps derived from GIS modeling and direct simulation techniques, paper presented at Joint Fire Science Conference and Workshop-Hazard and Risk Session, Univ. of Idaho, Boise.

Gabban, A., G. Liberta, J. San-Miguel, and P. Barbosa (2003), Forest fire risk estimation from time series analysis of NOAA AVHRR NDVI data, paper presented at Remote Sensing Europe, SPIE-Int. Soc. for Opt. Eng., Barcelona, Spain.

Jaeger, J. (2000), Landscape division, splitting index, and effective mesh size: New measures of landscape fragmentation, Landscape Ecol., 15, $115-130$.

Jappiot, M., R. Blanchi, and F. Guarnieri (2001), Système d'information géographique et modélisation dans le domaine de la prévention des incendies de forêts, in Information Géographique et Aménagement du Territoire, pp. 145-181, Hermès Sci. Publ., Paris.

Kalabokidisa, K. D., S. Gatzojannisb, and S. Galatsidas (2002), Introducing wildfire into forest management planning: Towards a conceptual approach, For. Ecol. Manage., 158, 41-50.

Keane, R. E., R. Burgan, and J. van Wagtendonk (2001), Mapping wildland fuels for fire management across multiple scales: Integrating remote sensing, GIS, and biophysical modeling, Int. J. Wildland Fire, 10(4), 301319 .

Kogan, F., A. Gitelson, E. Zakarin, L. Spivak, and L. Lebed (2003), AVHRR-based spectral vegetation index for quantitative assessment of vegetation state and productivity: Calibration and validation, Photogramm. Eng. Remote Sens., 69(8), 899-906.

Martin, M. P., L. Dominguez, and E. Chuvieco (1994), Estimating forest fire danger from AVHRR data, paper presented at 14th EARSel Symposium on Sensors and Environmental Applications, Eur. Assoc. of Remote Sens. Lab., Göteborg, Sweden.

Maselli, F. (2004), Monitoring forest conditions in a protected Mediterranean coastal area by the analysis of multiyear NDVI data, Remote Sens. Environ., 89, 423-433.

Maselli, F., A. Rodolphi, L. Bottai, and C. Conese (1996), Evaluation of forest fire risk by the analysis of environmental data and TM images, Int. J. Remote Sens., 17(7), 1417-1423.

Maselli, F., M. Chiesi, and M. Bindi (2004), Multi-year simulation of Mediterranean forest transpiration by the integration of NOAA-AVHRR and ancillary data, Int. J. Remote Sens., 25(19), 3929-3941.

Moisselin, J.-M., M. Schneider, C. Canellas, and O. Mestre (2002), Les changements climatiques en France au 20ème siècle. Étude des longues séries homogénéisées de données de température et de précipitations, Meteorologie, 38, 45-56.

Passot, X. (2001), VEGETATION image processing methods in the CTIV, paper presented at VEGETATION 2000 Conference, Cent. Natl. d'Etudes Spatiales, Belgirate, Italy.

Pereira, J. M. C., T. M. Oliveira, and J. C. P. Paul (1993), Fuel mapping in a mediterranean shrubland using Landsat TM imagery, paper presented at International Workshop on Satellite Technology and GIS for Mediterranean Forest Mapping and Fire Management, Eur. Comm., Thessaloniki, Greece.

Pettorelli, N., J. O. Vik, A. Mysterud, J. M. Gaillard, C. J. Tucker, and N. C. Stenseth (2005), Using the satellite-derived NDVI to assess ecological responses to environmental change, Trends Ecol. Evol., 20(9), 503-510.

Reed, B. C., J. F. Brown, D. VanderZee, T. R. Loveland, J. W. Merchant, and D. O. Ohlen (1994), Measuring phenological variability from satellite imagery, J. Veg. Sci., 5, 703-714.

Riano, D., E. Chuvieco, J. Salas, A. Palacios-Orueta, and A. Bastarrica (2002), Generation of fuel type maps from Landsat TM images and ancillary data in Mediterranean ecosystems, Can. J. For. Res., 32(8), $1301-1315$

Rouse, J. W., R. H. Haas, J. A. Schell, and D. W. Deering (1974), Monitoring vegetation systems in the Great Plains with ERTS, paper presented at Third Earth Resources Technology Satellite-1 Symposium, Sci. and Tech. Inf. Off., Washington D. C.

San-Miguel-Ayanz, J. (2002), Methodologies for the evaluation of forest fire risk: From long-term (static) to dynamic indices, paper presented at Forest Fires: Ecology and Control, Corso di Cult. in Ecol., Padua, Italy. Sebastián López, A., R. E. Burgan, and J. San-Miguel-Ayanz (2002), Assessment of fire potential in Southern Europe, in Forest Fire Research \& Wildland Fire Safety, edited by X. Viegas, pp. 1-15, Millpress, Rotterdam, Netherlands.

Trigo, R. M., R. García-Herrera, J. Díaz, I. F. Trigo, and M. A. Valente (2005), How exceptional was the early August 2003 heatwave in France?, Geophys. Res. Lett., 32, L10701, doi:10.1029/2005GL022410. van Wagtendonk, J. W., and R. R. Root (2003), The use of multi-temporal Landsat Normalized Difference Vegetation Index (NDVI) data for mapping fuel models in Yosemite National Park, USA, Int. J. Remote Sens., 24(8), 1639-1651.

Wang, Q., S. Adiku, J. Tenhunen, and A. Granier (2005), On the relationship of NDVI with leaf area index in a deciduous forest site, Remote Sens. Environ., 94, 244-255.

Zhang, X., M. A. Friedl, C. B. Schaaf, A. H. Strahler, J. C. F. Hodges, F. Gao, B. C. Reed, and A. Huete (2003), Monitoring vegetation phenology using MODIS, Remote Sens. Environ., 84, 471-475.

V. Chéret and J. P. Denux, Laboratory of Remote Sensing and Land Management, Graduate School of Purpan, 75 voie du TOEC, BP 57611, F-31076 Toulouse, France. (veronique.cheret@purpan.fr) 